\title{
First record of the flat needlefish Ablennes hians (Valenciennes, 1846) from Syrian marine waters (eastern Mediterranean)
}

\author{
Firas Alshawy ${ }^{1 *}$, Amir Ibrahim¹, Chirine Hussein ${ }^{1}$ and Murhaf Lahlah²
}

\begin{abstract}
Background: Climatic changes and human activities have worked to pave the way for alien species to invade new areas far from their native habitats. Belonidae species (Needlefishes), spread into wide water bodies, and some exist in the Mediterranean Sea.

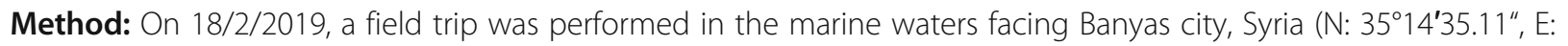
$\left.35^{\circ} 55^{\prime} 12.56^{\prime \prime}\right)$; to collect fish samples using a gillnet, with assistance of fishing boat ( $9.5 \mathrm{~m}$ and $19 \mathrm{HP}$ ). Fish individuals were identified, the morphometric measurements and meristic counts were recorded.

Results: Two individuals of the Flat Needlefish Ablennes hians were caught from the marine water facing Banyas city-Syria.

Conclusion: This study reveals that the Flat Needlefish A.hians exists in the marine waters of Syria (Eastern Mediterranean). It is recorded for the second time in the Mediterranean Sea, and Suez Canal is thought to be the main root of introduction.
\end{abstract}

Keywords: Flat needlefish, Ablennes hians, Suez Canal, Mediterranean, Syrian marine waters

\section{Background}

Climatic changes and human activities have worked to pave the way for alien species to invade new areas far from their native habitats (Sandilyan et al., 2018). Climate changes have made the environmental conditions suitable for species to leave their original habitat due to temperature increase, salinity increase and food habit changes (Vallerga et al., 2003, Drago et al., 2004, RAC, 2009., Ibrahim et al., 2010, Eissa and Zaki, 2011). Human activities, such as Suez Canal opening, and ships movement across the world, open the road for marine species to move into new environments (Ibrahim et al., 2002, Zenetos et al., 2004, AlShawy et al., 2017, Alshawy et al., 2019a,b). Up to now, more than 100 Lessepsian fish species had invaded the Mediterranean Sea from the Indian and $\mathrm{Pa}$ cific oceans and the Red Sea (Zenetos et al., 2012,

\footnotetext{
*Correspondence: falshawy@gmail.com; firas.ahmad.alshawy@tishreen.edu.sy 'Department of Marine Biology, High Institute of Marine Research, Tishreen University, Lattakia, Syria

Full list of author information is available at the end of the article
}

Boussellaa et al., 2018). Belonidae species (Needlefishes), spread into wide water bodies (Froese and Pauly, 2019), and some exist in the Mediterranean Sea (Whitehead et al., 1984, Carpenter and De Angelis, 2016). However, up to now, only two species of this family (Belone belone and Tylosurus choram) had been recorded in the marine waters of Syria (Ali, 2018). Hence, the present study reports that the Flat Needlefish Ablennes hians has been recorded for the first time in the marine waters of Syria, and for the second time in the eastern Mediterranean.

\section{Methods}

On $18 / 2 / 2019$, a field trip was performed in the marine waters facing Banyas city, Syria (N: 35⒈ $14^{\prime} 35.11^{\prime \prime}$, E: $35^{\circ} 55^{\prime} 12.56$; (Fig. 1) to collect fish samples using a gillnet (18 mm mesh size, $3 \mathrm{~m}$ height, $200 \mathrm{~m}$ length: with duplicates), with assistance of fishing boat (9.5 $\mathrm{m}$ and 19HP). Fish individuals were identified according to Carpenter and Niem (1999), Hailey (2011) and Roul et al. (2018). The morphometric measurements (length to the nearest 


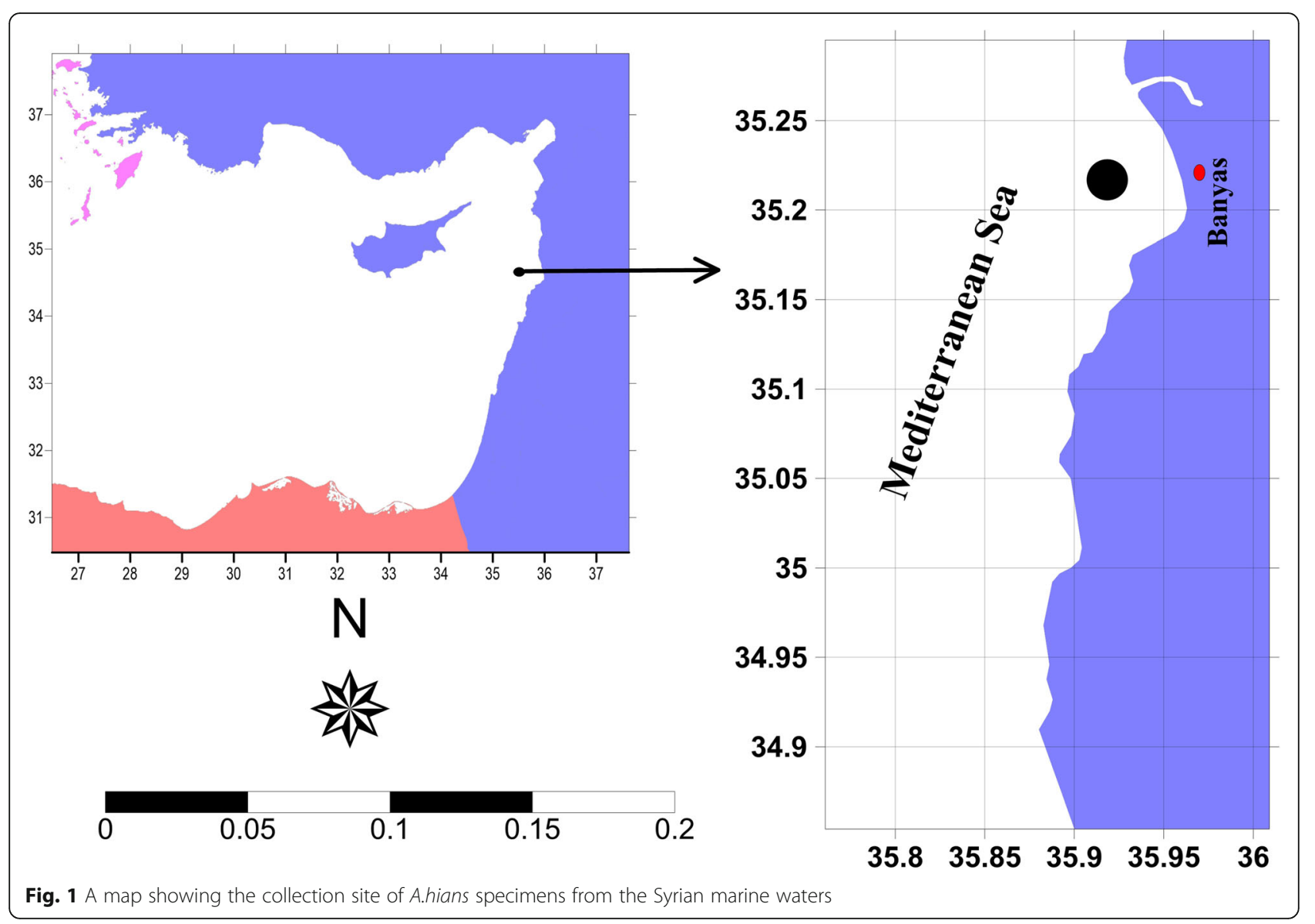

$\mathrm{mm}$, weight to the nearest g), and meristic counts were recorded. They were then photographed, preserved in 7\% formaldehyde and placed at the Fish Biological Laboratory of the High Institute of Marine Research -HIMR (Tishreen University - Lattakia, Syria) as reference samples.

\section{Results}

Two individuals of the Flat Needlefish Ablennes hians (Valenciennes, 1846) (Fig. 2) were caught. They have the following diagnostic characteristics: the body is elongated and compressed laterally, upper and lower jaws elongate with small sharp teeth. Front part of the dorsal and anal fins are longer than the rest of fins, and curved backwards. The caudal fin is forked. The body is coloured bluish green above and silvery white on sides. The dorsal and caudal fins and the lobes of the front part of the pelvic, pectoral and anal fins are black. Dark vertical bars cover the body. The morphometric measurements are shown in Table 1 and the fin formula is: $\mathrm{D}, 25 ; \mathrm{P}, 14 ; \mathrm{V}, 6 ; \mathrm{A}, 27 ; \mathrm{C}, 19$. These 2 individuals are females with single lobed ovary in pre-spawning stage. It should be noted here that the local fishermen had confirmed the existence of this

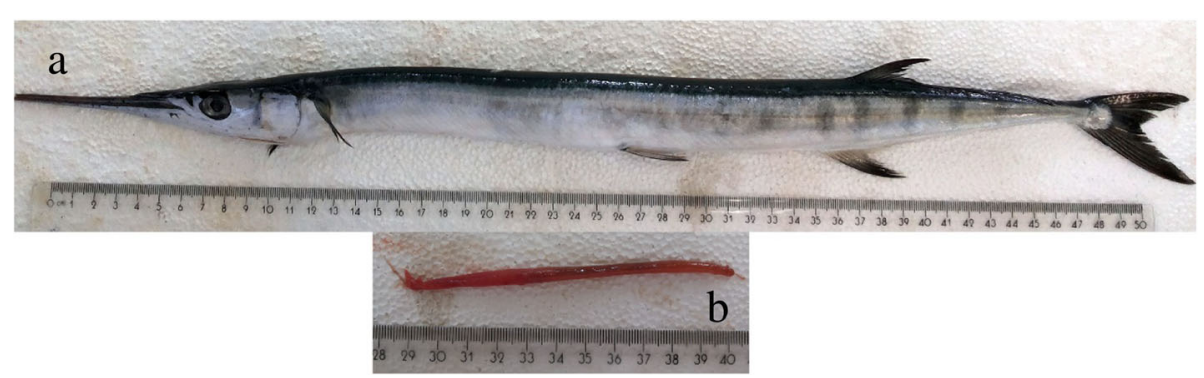

Fig. 2 a-A specimen of Flat Needlefish A.hians, caught on 18-2-2019 from Banyas coastal area, Syria. b-The ovary of the specimen 
Table 1 Morphometric measurements of A.hians captured from the coastal water of Banyas, Syria

\begin{tabular}{lll}
\hline Characteristics (mm or gr) & 1 st individual & 2nd individual \\
\hline Standard length & 445 & 502 \\
Total length & 500 & 553 \\
Body depth & 340 & 340 \\
Head length & 145 & 150 \\
Eye diameter & 15 & 15 \\
Jaw length & 96 & 104 \\
Dorsal fin length & 90 & 94 \\
Pectoral fin length & 34 & 35 \\
Pelvic fin length & 27 & 30 \\
Anal fin length & 93 & 98 \\
Caudal fin length & 54 & 60 \\
Pre-dorsal length & 342 & 378 \\
Pre-pectoral length & 153 & 154 \\
Pre-pelvic length & 264 & 291 \\
Pre-anal length & 330 & 387 \\
Ovary length & 115 & 110 \\
Total weight & 130 & 172 \\
Ovary weight & 1 & 1
\end{tabular}

species several times in their catches during the last few months.

\section{Discussion}

The Flat Needlefish A. hians spreads in tropical and subtropical waters (Eastern Atlantic, Western Atlantic, the Indian Ocean, Western Pacific, Eastern Pacific, and Red sea) (Carpenter, 1997, Carpenter and Niem, 1999, Carpenter and Niem, 2001, Golani and Fricke, 2018). A. hians had been recorded for the first time in the eastern Mediterranean (the coast of Netanya city) by Golani (2019); It had never been recorded in the western Mediterranean yet (Collette et al., 2015, Froese and Pauly, 2019). Therefore, the occurrence of this species in the eastern Mediterranean may largely due to its migration through the Suez Canal and its direction eastward. The previous record of this species in the Egyptian coast of the Red Sea (Golani and Fricke, 2018), and not that of other areas of Mediterranean Sea (Galil et al., 2015, Haroun et al., 2017, Golani and Fricke, 2018) supports this hypothesis. This record adds an additional species to fish checklist of the Syrian marine waters, and confirms that the changes in the environmental conditions of the Mediterranean facilitate species introduction (Coll et al., 2010, Hallom et al., 2014, Alshawy et al., 2019c). However, despite the presence of these two individuals, in addition to the previous observations of this species in the catches, more studies should be conducted to verify whether the Flat Needlefish $A$. hians had established itself in the marine water of Syria.

\section{Conclusion}

This study reveals that the Flat Needlefish A.hians exists in the marine waters of Syria. It has been recorded for the first time in this area, and for the second time in the eastern Mediterranean Sea. Suez Canal is thought to be the main root of introduction.

\section{Acknowledgements}

The authors thank Tishreen University and the High Institute of Marine Research, Lattakia who provided the financial and logistic supports to this work.

\section{Authors' contributions}

All authors have equal participation in this work. All authors read and approved the final manuscript.

Funding

The University of Tishreen, Syria.

Availability of data and materials

Data sharing not applicable to this article as no datasets were generated or analyzed during the current study.

Ethics approval and consent to participate

Not applicable.

\section{Consent for publication}

Not applicable.

\section{Competing interests}

The authors declare that they have no competing interests.

\section{Author details}

${ }^{1}$ Department of Marine Biology, High Institute of Marine Research, Tishreen University, Lattakia, Syria. ${ }^{2}$ Department of Public Health and Preventive Medicine, Faculty of Veterinary Medicine-Hama University, Hama, Syria.

Received: 22 March 2019 Accepted: 19 July 2019

Published online: 24 July 2019

\section{References}

Ali MF. An updated checklist of the marine fishes from Syria with emphasis on alien species. Mediterr Mar Sci. 2018;19:388-93.

Alshawy F, Ibrahim A, Hussein C, Lahlah M. First record of the blacktip cardinalfish Apogon atradorsatus Heller \& Snodgrass, 1903 from Syrian marine waters (eastern Mediterranean). International Journal of Advanced Research in Science, Engineering and Technology. 2019a;6:5.

Alshawy F, Ibrahim A, Hussein C, Lahlah M. First record of the Broadbanded cardinalfish Ostorhinchus fasciatus (white, 1790) from the Syrian marine waters (eastern Mediterranean). International Journal of Agriculture \& Environmental Science. 2019b;6:14-6.

Alshawy, F., Ibrahim, A., Hussein, C. \& Lahlah, M. First record of the oceanic puffer Lagocephalus lagocephalus (Linnaeus, 1758) from the Syrian marine waters (eastern Mediterranean). Marine Biodiversity Records 2019c. Marine Biodiversity Records 2019;12:1. 11

Alshawy FA, Lahlah MM, Hussein CS. First record of the Lessepsian migrant Smith's cardinalfish Jaydia smithi Kotthaus, 1970 (Pisces: Apogonidae) from Syrian marine waters. Basrah Journal of Agricultural Sciences. 2017;30:45-9.

Boussellaa W, Neifar L, Goedknegt MA, Thieltges DW. Lessepsian migration and parasitism: richness, prevalence and intensity of parasites in the invasive fish Sphyraena chrysotaenia compared to its native congener Sphyraena sphyraena in Tunisian coastal waters. PeerJ. 2018;6:e5558.

Carpenter, K. E. Living marine resources of Kuwait, eastern Saudi Arabia, Bahrain, Qatar, and the United Arab Emirates. FAO Rome; 1997. 
Carpenter, K. E. \& De Angelis, N. The living marine resources of the eastern Central Atlantic bony fishes part 2(Perciformes to Tetradontiformes) and sea turtles. FAO Rome;2016.

Carpenter, K. E. \& Niem, V. H. The living marine resources of the western central pacific volume 4 bony fishes part 2 (mugilidae to carangidae) FAO Rome;1999.

Carpenter, K. E. \& Niem, V. H. FAO species identification guide for fishery purposes. The living marine resources of the Western Central Pacific. Volume 4 bony fishes part 2 (Mugilidae to Carangidae) FAO Rome;2001.

Coll M, Piroddi C, Steenbeek J, Kaschner K, Lasram FBR, Aguzzi J, Ballesteros E, Bianchi CN, Corbera J, Dailianis T. 2010. The biodiversity of the Mediterranean Sea: estimates, patterns, and threats. PLoS One. 2010;e11842:5.

Collette, B., Polanco Fernandez, A. \& Aiken, K. A. Ablennes hians. The IUCN Red List of Threatened Species 2015

Drago A, Aarup T, Abdelbaki A, et al. MEDGOOS-building a strong regional partnership for operational oceanography in the Mediterranean. J Rapports et proces verbaux des réunions-Commission internationale pour l'exploration scientifique de la mer Méditerranée. 2004;37:158.

Eissa AE, ZAKI MM. The impact of global climatic changes on the aquatic environment. Procedia Environ Sci. 2011;4:251-9.

Froese, R. \& Pauly, D. Fishbase www. fishbase. in. 2019 www.fishbase.in . 22 Mar 2019.

Galil BS, Boero F, Campbell ML, Carlton JT, Cook E, Fraschetti S, Gollasch S, Hewitt $\mathrm{CL}$, Jelmert A, Macpherson E. 'Double trouble': the expansion of the Suez Canal and marine bioinvasions in the Mediterranean Sea. Biol Invasions. 2015; 17:973-6.

Golani D. First record of the flat needlefish Ablennes hians (Valenciennes, 1846) in the Mediterranean Sea (Osteichthyes, Beloniformes, Belonidae). Biolnvasions Records. 2019;8.

Golani D, Fricke R. Checklist of the Red Sea fishes with delineation of the Gulf of Suez, Gulf of Aqaba, endemism and Lessepsian migrants. Zootaxa. 2018:4509:1-215.

Hailey, A. The online guide to the animals of Trinidad and Tobago. The University of the West Indies, St Augustine.2011.

Hallom N, Ibrahim A, Galiya MJMBR. First record of the hen-like blenny Aidablennius sphynx (Blenniidae) from Syrian marine waters (eastern Mediterranean). Marine Biodiversity Records. 2014;7:2.

Haroun ES, Akel K, Karachle PK. The marine ichthyofauna of Egypt. The Egyptian Journal of Aquatic Research. 2017;21:81-116.

Ibrahim A, Karroum M, Lahlah M. Marine fish biodiversity of Syria: nine new records. J Env and Res Sust Arab Uni Union. 2002;5:68-93.

Ibrahim A, Lahlah M, Kassab M, Ghanem W, Ogaily S. Signatus javus, a new record from the Syrian waters, with reference to growth and feeding of two Lessepsian fish. Rapport de la Commission international de la Mer. Méditerrané. 2010;39:544.

RAC, U.M., SPA. Sub-regional report on vulnerability and impacts of climate change on marine and coastal biological diversity in the Mediterranean, Arab Countries. By Ben Haj, S., Cebrian, D., Limam, A., Grimes, S., Halim, Y, Bitar, G., Bazairi, H., Ibrahim, A., Romdhane, MS, Ed. RAC/SPA, Tunis.2009.

Roul, S. K., Abdussamad, E., Rohit, P. \& Jaiswar, A. K. New distributional record of flat needlefish Ablennes hians (Valenciennes, 1846)(beloniformes: belonidae) in the north-eastern indian ocean with taxonomic details. Thalassas: An International Journal of Marine Sciences 2018;1-5pp.

Sandilyan, S., Meenakumari, B., Biju Kumar, A. \& Mandal, R. A review on impacts of invasive alien species on Indian inland aquatic ecosystems. National Biodiversity Authority, Chennai. In: se. Condary Sandilyan, S., Meenakumari, B., Biju Kumar, a. \& Mandal., R. (eds.). Centre for Biodiversity Policy and Law.2018. 456-462pp.

Vallerga, S., Drago, A., Aarup, T., Abdelbaki, A., Abuissa, A., Awad, H., Awad, M. Beken, C., Besiktepe, S., Boargob, A., Brundrit, G., M Capari, A. C., Cermelj, B., Casazza, G., Civili, F., Y Cohen, C Tziavos, H. D., Costa, M. D., P Drakopoulos, N. F., J Font, G. F., I Gertman, G. G., Harzallah, A., Herrouin, G., Ibrahim, A. Kabbara, N., Kljajic, Z., Kouyoumjian, H., Legrand, J., J Lopez-Jurado, Magni P Mahmoud A, A-Sheikh, Maillard, C, Malacic, V, Gmr Manzella, Marchand, P. Morovic, M, Pissierssens, P, Pinardi, N, Nittis K, D R, Summerhayes, C, Ribotti, A, Reed, G, Selenica, A, Salihoglu, I, Sammari, C, Sauzade, D, Silvestri, C, Snoussi, M, Sorgente, R, Umgiesser, G, Vargas, M, Vucijak, B, Woods, J, Zavatarelli, M \& Zodiatis, G MAMA-Towards a new paradigm for ocean monitoring in the Mediterranean Elsevier Oceanography Series;2003:46-56.

Whitehead, P. J. P Bauchot, M. Hureau, J Nielsen, J \& Tortonese, E. Fishes of the North-Eastern Atlantic and the Mediterranean. v. 1.1984.1473.
Zenetos, A., Dosi, A., Abatzopoulos, T., Triantafyllidis, A., Bejaoui, N., Soufi, E., Ammar, I., Ibrahim, A. Study to investigate an invading bioindicator in the Mediterranean, Pinctada radiata (Leach, 1814). Study group on Ballast and other ship vectors ICES/IOC/IMO, Cesenatico, Italy,.2004; 376

Zenetos, A., Gofas, S., Morri, C., Rosso, A., Violanti, D., Raso, J. E. G., M.E. Cinar, A. AL., Ates, A. S., Azzurro, E., Ballesteros, E., Bianchi, C. N., Bilecenoglu, M., Gambi, M. C., Giangrande, A., Gravili, C., Hyams-Kaphzan, O., P. K. Karachle, S. K., L. Lipej, F M., F. Mineur, M.A. P-P, Espla, A. R., C. Salas, G. S M., A. Sfriso, N. S. \& Verlaque, M. 2012. Alien species in the Mediterranean Sea by. A contribution to the application of european union's marine strategy framework directive (MSFD). Part 2. Introduction trends and pathways. Mediterr Mar Sci 2012;13, $328-352$

\section{Publisher's Note}

Springer Nature remains neutral with regard to jurisdictional claims in published maps and institutional affiliations.
Ready to submit your research? Choose BMC and benefit from:

- fast, convenient online submission

- thorough peer review by experienced researchers in your field

- rapid publication on acceptance

- support for research data, including large and complex data types

- gold Open Access which fosters wider collaboration and increased citations

- maximum visibility for your research: over $100 \mathrm{M}$ website views per year

At BMC, research is always in progress.

Learn more biomedcentral.com/submissions 